\title{
I sandhedens grænseland
}

\section{En analyse af presseetiske dilemmaer i Ekstra Bladets dækning af ubådssagen}

\author{
AF MARIA BENDIX WITTCHEN
}

\section{Resumé}

Da den såkaldte ubådssag startede, begyndte en sideløbende omfattende politiefterforskning og mediedækning af den drabssigtede Peter Madsen og den forsvundne/døde journalist Kim Wall. Denne artikel har et presseetisk perspektiv på dækningen, og gennem analyse af Ekstra Bladets journalistik diskuteres de presseetiske grænser og gråzoner, der opstår, når tabloidjournalisterne træder ind i en detektivrolle og efterligner politiets arbejdspraksis, samtidig med at de både skal levere fascinerende fortællinger med følelsesappel og er underlagt presseetiske regler. Studiet dokumenterer og diskuterer presseetiske dilemmaer, der opstår i relation til især motivspekulation, kildebrug, og når den hovedmistænkte er kendt i offentligheden.

\section{Introduktion}

Mord, vold og anden kriminalitet har som stofområde en lang tradition (Chibnall 1981, Katz 1987, Orre 2001, Pollack 2001), og det har historisk set primært haft sin plads i formiddagsaviser og tabloidmedier (Lehrmann 2011, 2016). De senere års stigende kommercialisering og tabloidisering i medierne betyder imidlertid, at man i dag kan læse, se og høre om kriminalitet på stort set alle medieplatforme og i alle medietyper (Agger 2013, Allern 2013, Brurås 2009:178ff). Kriminaljournalistikken kritiseres ofte 
for at være sensationshungrende, underholdende og for at bruge litterære fortællegreb, så læseren kan komme i tvivl om, hvorvidt der er tale om fiktion eller fakta. Kriminaljournalistikken gives imidlertid også legitimitet, fordi medierne er borgernes primære kilde til information om politiets og domstolenes arbejde (Borberg 2012), det vil sige den udøvende og dømmende magt, og på grund af idealet om pressen som vagthund kan justitsmord og fejl i politiarbejdet afsløres (Røssland 2003:137ff).

Den eksisterende forskning i kriminaljournalistik herhjemme deler sig i to hovedretninger: Den ene handler om mediefremstillingen af kriminalitet sammenlignet med den reelle kriminalitet i samfundet (Lund 2003, Lund og Jensen 2011), mens den anden fokuserer på, hvordan træk fra fiktionslitteratur siver ind i den faktabaserede journalistik, hvormed journalistikken har et ekstra fokus på fortællingen og "den gode historie" (Bondebjerg 2002, Lehrmann 2016). Lehrmanns studier peger netop på, at Ekstra Bladets kriminaljournalistik - som dette studie også undersøger - gennem årene i stigende grad har fokus på en oplevelsesappellerende vinkling, hvor læseroplevelsen minder om kriminalog suspenselitteratur (Lehrmann 2016:93f). Udviklingen mod flere personlige vinkler ses også i USA og Storbritannien (Wardle 2006). Denne artikel placerer sig i den sidste retning. Teoretisk har jeg også en presseetisk tilgang og bidrager derved med et overset perspektiv på kriminaljournalistikken i en dansk forskningskontekst (se dog Larsen 2010).

\section{Politi og presse: to detektivtyper}

Forholdet mellem politi og presse er også centralt i denne kontekst. På grund af politiets magtbeføjelser er der tale om en særlig type kilde (Sparre 2002), og flere beskriver et komplekst afhængighedsforhold mellem netop journalister og politi (Chibnall 1975, Mawby 2010, Shpayer-Makov 2009), hvor politiets brug af medierne som redskab i efterforskningen problematiseres (Innes 1999). Flere har identificeret ligheder mellem politiets og journalisters arbejdsmetoder (Danielson 2016, Dobovšek og Mastnak 2012, Shpayer-Makov 2009), hvilket er relevant i dette 
studie, hvor jeg netop undersøger presseetiske dilemmaer, der opstår, når journalister træder ind i en detektivrolle og efterligner dele af politiets efterforskningspraksis i jagten på nye vinkler. Centrale fællestræk for "journalistdetektiver" og politiefterforskere er at indsamle informationer om den konkrete sag, hvilket især handler om at søge svar på hvem, hvorfor og så videre, at få verificeret informationer hos forskellige kilder og interviewe vidner/parter i sagen (Dobovšek og Mastnak 2012:294). Et yderligere fællestræk for de to detektivtyper er arbejdet med at opridse den hovedmistænktes såkaldte moralske karriere for at afdække, hvorvidt han/hun "har det i sig" (Innes 2003:7ff, Mannov 2013).

Det er oplagt at stille skarpt på kombinationen af kriminalstoffet og presseetik, da udviklingen af de presseetiske regler herhjemme som i resten af Norden historisk er drevet frem af kritik af netop kriminaljournalistik (Allern 2013:317). I presseetisk sammenhæng er en hovedtematik risikoen for at hænge borgere ud, før de er dømt i retten, hvormed medierne flytter sig fra idealrollen som den fjerde statsmagt og overtager den dømmende magts rolle (Anonym 2016, Brurås 2000, Frenningsmoen 2006). Dette var allerede et centralt tema, da de første presseetiske regler blev vedtaget i Danmark (Andersen 2006). De var målrettet omtale af straffesager og indeholdt påbud som "Kald ingen skyldig, før han er dømt!" og "Tiltale er ikke dom!" (Danske Dagblades Fællesrepræsentation 1960). Lignende punkter vedrørende kriminalstoffet har stadig en central plads i de vejledende regler for god presseskik anno 2018 (Pressenævnet 2013), der i dag er en del af medieansvarsloven. I analysen vil jeg inddrage de konkrete vejledende regler for god presseskik, hvorfor de kort introduceres her. Reglerne består af nogle grundlæggende synspunkter og dertil tre afsnit, der omhandler 1) korrekte meddelelser, 2) adfærd i strid med god presseskik og 3) retsreportage, som også inkluderer hele efterforskningsprocessen op til en eventuel retssag (se Pressenævnet 2013 for hele regelsættet). Det fremgår, at ytringsfriheden er grundlaget for journalisternes arbejde, og med denne frihed følger et krav om, at medierne skal tage"(...) hensyn til den enkelte borgers krav på respekt for den personlige integritet og privatlivets fred og til behovet for beskyttelse mod ubeføjet krcenkelse" (Pressenævnet 2013). Der er altså tale om en kamp 
mellem relevans og hensyn, idet en historie med klar almen interesse godt må krænke en borgers integritet. Dykker man yderligere ned i de konkrete anvisninger vedrørende kriminaljournalistikken, skal retsreportagen være objektiv, og journalisterne må ikke forhåndsdømme ved at publicere tilkendegivelser om, at en sigtet eller tiltalt er skyldig, så længe en straffesag kører. Reglerne er som nævnt vejledende og dermed langt fra entydige, hvorfor det er op til journalister og medier (eller i sidste ende Pressenævnet) at forhandle og fortolke reglerne i praksis.

\section{Forskning i presseetik}

Presseetik har ikke haft et stort forskningsfokus i en dansk kontekst, hvis man sammenligner med de andre nordiske lande. Man har typisk undersøgt den historiske udvikling (Andersen 2006) og journalisters forhold til de vejledende regler for god presseskik (Blach-Ørsten og Burkal 2014, Blach-Ørsten mfl. 2015, Buch 2006). Det danske mediesystem er kendetegnet ved et institutionaliseret pressenævn og fælles vejledende regler for god presseskik. I litteraturen argumenteres der for, at både pressenævn og regler skal anskues som selvregulering, der bekæmper politisk censur via selvjustits (Andersen 2006:29), og at disse selvreguleringsredskaber er med til at påvirke mediers troværdighed og ansvarlighed i en positiv retning (Blach-Ørsten og Burkal 2014, Fengler mfl. 2014). Branchens stigende brug af interne etiske retningslinjer har også været fokus i flere studier (BlachØrsten mfl. 2015, Kruuse 1991, Skovbjerg og Jørgensen 2006). En stor del af den danske forskning har altså, ligesom størstedelen af den nordiske, et empirisk fokus, når man anskuer presseetikken i forhold til blandt andet konkret praksis og aktørerne. Det er også den tilgang, dette studie har. Ligesom tidligere studier afgrænser denne artikel sig fra en filosofisk diskussion af etik (se dog Bjerg 2009, Keeble 2001, McBride og Rosenstiel 2014) og taler for et mere professionsnært og pragmatisk syn på den journalistiske etik: Her kan presseetikken defineres som "(...) formelle og uformelle handlingsanvisninger på, hvad journalister og medier bør gøre og mere specifikt, hvad de ikke bør gøre i en given situation for dermed at mindske de negative konsekvenser, journalistikken 
kan have for samfundet, kilderne, journalisten og journalistens ansaettelsessted, samt dem og det, der behandles i det journalistiske produkt" (Blach-Ørsten mfl. 2015:7).

\section{Etik og krim går hånd i hånd}

I andre nordiske lande findes en del presseetikforskning og litteratur med særligt fokus på netop kriminaljournalistik (Brurås 2009, Kvam 2002, Røssland 2003, Røssland mfl. 2006), og flere casestudier undersøger dækningen af drabssager med presseetik som tematik (Brurås og Røssland 2005, Delbro og Juliusson 2017). Herhjemme har Ulrik Lehrmann (2011) kortlagt udviklingen i Ekstra Bladets kriminaljournalistik fra 1966 til 2006 og påviser et skifte fra de udelukkende faktaorienterede, deskriptive politivinkler til fortællende og følelsesladede melodramaer med stærk læserappel samt en udviskning af grænsen mellem fakta og fiktion. Krimi-tabloidjournalisternes opgave er stadig at levere fakta, men skal også minde læseren om dennes "eksistens, udsathed og dødelighed" (Lehrmann 2016:94). Dertil skal journalisten hjælpe læseren med at begribe den meningsløse forbrydelse samt levere drama og suspense, og i den sammenhæng indtager journalisten ofte en form for fiktionskarakter, nemlig den klassiske detektivrolle (Lehrmann 2011:186f).

\section{Metode}

Ovenstående gennemgang af forskningsfeltet og de presseetiske regler understreger, at kriminaljournalistikken og detektivrollen rummer en række presseetiske dilemmaer. Der er tre primære grunde til, at det er særligt interessant at undersøge netop den del af kriminaljournalistikken, hvor journalisternes praksis minder om politiets arbejdsmetoder i forsøget på at finde nye, selvstændige vinkler. For det første kan journalisters parallelefterforskning spænde ben for politiets arbejde eller påvirke vidner, hvilket Kvam tidligere har påpeget (se Kvam 2002:63ff), men omvendt kan journalisterne også være med til at finde for eksempel nye vidner eller spor. For det andet er dette fokus så vidt vides 
underbelyst i litteraturen herhjemme. Lehrmann har tidligere inddelt kriminaljournalistikken i tre overordnede synsvinkler: 1) den politimæssige undersøgelse, 2) de tekniske og videnskabelige elementer, der er relateret til den konkrete forbrydelse, samt 3) de melodramatiske vinkler, hvoraf de sidstnævnte - melodramaerne med fiktionstræk - i stigende grad dominerer krimjournalistikken (Lehrmann 2016:97f). I denne sammenhæng argumenterer jeg for, at 'journalisten som detektiv' kan ses som en udvidelse af melodrama-synsvinklen eller sågar som en fjerde synsvinkel. Artiklens fokus bidrager således med en nuancering af krimidækningen og dermed også med ny viden inden for feltet. For det tredje er der elementer, der kendetegner netop denne synsvinkel, som kan være presseetisk problematiske. Det handler blandt andet om, at en del af journalistdetektivvinklerne ikke bygger på bastant faktaformidling (ibid:116), men derimod på motivspekulationer og vurderinger, der kan være svære at verificere, samt fiktionsprægede personbeskrivelser af de involverede.

Jeg vælger at undersøge dele af Ekstra Bladets dækning af ubådssagen, og medievalget har flere årsager: Tabloidmedierne er et oplagt valg, hvis man vil undersøge egenproduceret kriminaljournalistik (Lund 2003:168), og her anses Ekstra Bladet for at være "frækkere og mere aggressiv i sin journalistik" end BT (Lehrmann 2016:89f). Ekstra Bladet har dertil haft flest klager i Pressenævnet fra 1992-2013 (Blach-Ørsten mfl. 2015:20), og mediet påpeger selv, at man producerer journalistik, der "går til kanten, i et højt tempo. Det stiller store krav til vores etiske dømmekraft" (Ekstrabladet.dk 2018).

Valget af ubådssagen som case kan betegnes som en ekstrem case (Flyvbjerg 2006:229f) både i forhold til det spektakulære hændelsesforløb, og fordi den blev dækket intensivt af både danske og udenlandske medier i 2017. Som udgangspunkt er kombinationen af kendis (i denne sag Peter Madsen) og forbrydelser journalistisk set "en god historie" (Grabe 2000), og denne sag indeholder yderligere elementer, som bidrager til en ekstraordinær tabloidhistorie: en bestialsk forbrydelse/ulykke, et sensationelt gerningssted (ubåden), sexhistorier, skiftende forklaringer, en elskerinde, omfattende og dragende billeddækning og blodige 
detaljer med blandt andet afhuggede lemmer. Det lyder som en fiktionsfortælling, et klassisk locked room mystery under havet, men er en mulig drabssag fra virkeligheden, hvor den mediekendte amatøropfinder Peter Madsen indtager hovedrollen som den mulige bøddel, mens den ambitiøse, smukke Kim Wall, der var på ubåden i en højere sags tjeneste, nemlig journalistikken, er et "ideal victim" (Greer 2007), der ikke "blot" er død, men også parteret. Norske medieforskere har tidligere argumenteret for relevansen af at undersøge en intenst dækket kriminalsag. De mener, at sådanne sager i særlig grad udstiller og tydeliggør de presseetiske udfordringer, journalisterne står over for, hvormed relevansen af konklusionerne rækker ud over den konkrete case (Røssland mfl. 2006:10).

Analysen har fokus på de produktioner, hvor journalisten efterligner politiarbejdet og indtræder i en detektivrolle. For at udvælge disse indsamles og læses først alle nyhedsartikler, Ekstra Bladet har publiceret i perioden 11.08.2017 (ubåden forsvinder) til 07.03.2018 (dagen inden retssagen mod Peter Madsen begynder), i Ekstra Bladet og på ekstrabladet.dk. Det sker via artikeldatabasen Infomedia. Ledere, opinionsstof og Ekstrabladet+ fravælges. Det samlede artikelkorpus består af 456 artikler. Disse læses for at få overblik over sagen og dennes særegenhed. På baggrund af litteraturen om fællestræk i arbejdsmetoder mellem politi og journalister (Dobovšek og Mastnak 2012, Innes 2003, Mannov 2013) identificeres artikler med detektivtræk. Disse er kendetegnet ved 1) at søge svar på forbrydelsens primære spørgsmål, som forsøges verificeret hos forskellige kilder. 2) Interviews med vidner og/eller kilder tæt på sagen og dennes hovedpersoner. 3) Detaljerede personbeskrivelser, som kan sige noget om, hvorvidt den formodede gerningsmand "har det i sig". Der identificeres 94 artikler med detektivtræk, der har enten et eller flere af ovenstående tre karakteristika. Med afsæt i de vejledende regler for god presseskik samt litteraturgennemgangen om kriminaljournalistik og presseetik nærlæses (Patton 2002) tekstkorpusset på 94 artikler for at udvælge og diskutere fremtrædende eksempler på de presseetiske dilemmaer, der opstår i dækningen af den konkrete sag, når journalisterne indtræder i detektivrollen. 
Til analysens første del udvælges artikeleksempler fra dækningen, hvor journalisterne forsøger at søge svar på forbrydelsens spørgsmål, hvilket i den konkrete sag i høj grad er kendetegnet ved spørgsmålet om, hvorfor Peter Madsen skulle/kunne have slået Kim Wall ihjel. Til analysens anden del fokuserer jeg på interviews med vidner, hvorfor eksempler på artikler inddrages, som kan illustrere de presseetiske udfordringer, der er i den konkrete sag, hvor journalisterne i høj grad udfordres af, at ingen vidner har været på ubåden. I analysens tredje del behandles det faktum, at den hovedmistænkte er kendt, og hvilke etiske dilemmaer, der opstår, når journalisterne afdækker hans moralske karriere. I alt inddrages 13 artikler i den følgende tekstanalyse (Jensen 1997).

\section{Analyse}

\section{Jagten på svar - kunsten at motivspekulere kvalificeret}

I enhver mulig drabssag er der en række spørgsmål, der rejser sig i opklaringsarbejdet, både for politiet og for journalistdetektiven: Hvad skete der egentlig? Hvem gjorde hvad? Og ikke mindst hvorfor? Det sidstnævnte, nemlig motivet, er afgørende for at forstå og opklare forbrydelsen. Klassiske motiver kan handle om seksuelle forhold, hævn eller penge (Wright 2013:186). I ubådssagen er der i 10 dage intet lig, men derimod en drabssigtelse og en hovedmistænkt, der nægter sig skyldig i drab. Læserne vil naturligt søge en forklaring på blandt andet et muligt motiv, hvilket journalisterne imidlertid ikke entydigt kan give. I dækningen præsenterer Ekstra Bladet dog læserne for en række hypoteser, altså en række bud på motiver. Et seksuelt motiv præsenteres allerede på dag tre i sagen i artiklen Tidligere drabsefterforsker om ubådsmysteriet: Liget er den vigtigste brik (eb.dk, 13/8). Efterfølgende artikler som Peter er ikke en pervers sadist (EB, 9/9/17), Forsvarsadvokat: Sexfilm kan foelde Peter Madsen (eb.dk, 10/9/17) og Drabsekspert om nye oplysninger: Styrker mistanken om seksuelt motiv (EB, 4/10/17) kredser også om netop dette motiv. 
I den første artikel, som læserne som nævnt allerede får på dag tre i sagen, og som jeg her vil gå i dybden med, legitimeres motivspekulationen ved, at journalisterne bruger den forhenværende drabsefterforsker Kurt Kragh som kilde, og han fungerer derfor som en form for detektivkollega. Forskning i efterforskning viser, at efterforskeres erfaring fra tidligere kriminalsager spiller en markant rolle i opklaringsarbejdet (Innes 2003), hvorfor Kragh med sin fortid som drabsefterforsker og kriminalkommissær ved Rigspolitiets rejsehold er en troværdig kilde. Under mellemrubrikken "Seksuelt motiv" fremlægges Kraghs bud på et motiv. Jeg har kursiveret journalistens og Kraghs forbehold. "Hvis det er Peter Madsen, der står bag den unge journalists forsvinden, så har Kurt Kragh en teori om, at der formentligt er tale om et seksuelt motiv på grund af de lukkede døre under grundlovsforhøret, som var begrundet med 'krænkende informationer'. - Der er formentlig sket et eller andet af seksuel karakter. Hvad der er sket, er ikke til at vide. Det har i hvert fald sandsynligvis ført til, at hun er blevet dræbt, siger han."

Journalisten forsøger - på vegne af læseren - her at skabe en mening med forbrydelsen ved at "(...) kitte det ellers uforståelige sammen" (Lehrmann 2016:17), da det på dette tidspunkt er uforståeligt for de fleste, om og i så fald hvorfor Madsen skulle have slået Wall ihjel. Artiklen forsøger ikke at give læseren et klart svar med konkret dokumentation, men giver et bud på motivet. Set i lyset af kildens autoritet og de mange forbehold synes motivanalysen både sandsynlig og kvalificeret. Dilemmaet for journalisten er imidlertid, at man på dette tidspunkt er meget tidligt $\mathrm{i}$ forløbet, og at journalisterne på den ene side skal imødekomme læserbehovet på en lødig måde, men på den anden side også skal videregive korrekte oplysninger samt udvise "størst muligt hensyn" over for offer, den sigtede og deres pårørende. Her må en presseetisk overvejelse være, hvorvidt motivspekulationen er for skræmmende læsning for Walls pårørende, at Wall (hvis lig ikke er fundet endnu) måske er blevet udsat for et seksuelt overgreb. Ligeledes sætter det den varetægtsfængslede Peter Madsen i et endnu dårligere lys - han mistænktes nu ikke blot for drab, men også for sexkrænkelser. Den sidste pointe skal ses i lyset af den tidligere sag fra Herning, Maria-drabet, hvor en sigtet mand var 
på forsiden af netop Ekstra Bladet, men hvor alle anklager om drab frafaldt, og en anden blev dømt (Larsen 2010).

Senere i dækningen bringes et andet klassisk motiv i spil for læserne, nemlig det økonomiske. Motivet præsenteres indirekte via udtalelser fra Thomas Djursing, forfatter til biografien Raket Madsen fra 2014. Djursing arbejder på interviewtidspunktet på en højaktuel føljeton om den verserende ubådssag, og i den forbindelse interviewes han af Ekstra Bladet under hovedoverskriften Forfatter med kontakt til Madsen i foengslet. Ifølge Djursing var Peter Madsen " $i$ stigende grad presset og stresset økonomisk. Han kunne ikke få penge ind til alt det, han gerne ville. Han kunne ikke få alle de rigtige folk ind. Det var ved at 'faile' for ham. Og det kan godt voere, at han siger, at det var det ikke, men det var det. Det ved jeg også fra hans noermeste folk. Det er der ikke noget galt $i$, og det gør ham ikke til kriminel, men det er med til at tegne et billede af, hvem han er, og hvad der skete i dagene op til." (EB og eb.dk 27/12). Foruden den pressede økonomi fortæller Djursing, at Madsens "livsmission" er ved at falde fra hinanden, og at ubådsbyggeren er "begyndt at gå ned med sit projekt". Dermed forstærkes fortællingen om en mand på deroute.

Kildemæssigt synes Djursing troværdig, da han gennem en årrække har fulgt Peter Madsen, og han har for nylig været i brevkontakt med den varetægtsfængslede Madsen. Trods kildens forbehold - "det gør ham ikke til kriminel" - så får man via beskrivelserne af ubådsbyggeren indtryk af, at Madsens økonomiske og personlige nedtur kan have fået det til at slå klik for ham. Da artiklen publiceres, har mediedækningen og politiefterforskningen af ubådssagen stået på i flere måneder, og der er stadig et utal af ubesvarede spørgsmål, som både politi, journalister og læsere søger svar på - ikke mindst hvorfor han parterede Wall, hvilket han på dette tidspunkt har erkendt at have gjort. I den sammenhæng præsenterer journalisten her en sandsynlig beskrivelse af den hovedmistænktes livssituation, og dermed tilbydes læserne et nyt bud på en forklaring af det uforståelige. I samme avisopslag konstaterer forfatteren, at "alt, hvad Peter gør, er jo grænsesøgende", hvilket styrker forestillingen om, at en excentrisk 
mand, der er ved at miste sit livsværk, kan blive drevet derud, hvor han parterer et lig og måske endda står bag drab.

Dilemmaet for journalisten er her, at der på den ene side er tale om spekulation i forhold til fortællingen om, at det muligvis slog klik for Madsen, og at han af pengemæssige og personlige årsager endte med at stå bag en brutal forbrydelse. Selvom kilden er troværdig, så kan man diskutere, hvor sandsynligt det reelt er, at dårlig økonomi og et opfinderprojekt i opløsning skulle være årsag til, at Madsen skal have forårsaget Walls død og derefter skåret hendes krop i stykker. Djursing tager også forbehold, men historien om Madsens nedtur træder imidlertid stadig tydeligt frem. På den anden side kan man argumentere for, at det for en tabloidavis er journalistisk relevant at forklare læserne, hvordan Madsens situation var på det givne tidspunkt, da det kan hjælpe dem med at begribe den brutale sag. Samtidig har ovenstående fortælling klar følelsesappel, hvorfor det er oplagt for Ekstra Bladet at bringe den. Via Djursing leverer journalisten et fortættet melodrama om et menneske, der er på vej til at miste alt og derfor angiveligt drives til at gøre noget utilgiveligt, og journalistikken er derved med til at skabe midlertidig mening for læseren på et tidspunkt, hvor sagen langt fra er opklaret, men hvor ønsket om nye vinkler og flere svar er konstant. Presseetisk er udfordringen imidlertid, at denne mening ikke nødvendigvis er korrekt.

\section{Jagten på vidner}

Øjenvidner er en klassisk kilde i både journalistik og politiefterforskning, hvorfor det også er en opgave for kriminalreporterne, at de som detektiver opsøger vidner, som kan belyse hændelsen. En markant forskel på politidetektiven og journalistdetektiven er imidlertid offentligheden: Journalisten arbejder for at publicere historier til læserne, det gør politiet ikke. Udfordringen i ubådssagen er, at der ikke var vidner til den potentielle forbrydelse under havets overflade, men dog til timerne op til. For eksempel får læserne historien Øjenvidne til ubådsforlis: "Kaptajnen stod helt roligt i tårnet" (eb.dk, 11/8/17) og Rasmus mødte Peter og Kim: Han tog sig god tid til at snakke (eb.dk, 15/8/17). Vidnerne fortæller her om situationer kendetegnet ved ro og god stemning, der 
på mystisk vis står i stærk kontrast til, at der få timer senere angiveligt skal være foregået et drab. Det lader dog til, at et umætteligt behov for nye vinkler får journalisten til at publicere på baggrund af det, man kan kalde pseudovidner, som ikke har set noget, men derimod tror eller føler noget. Dette ses i artiklen Hvor er liget af Kim Wall? (EB, 18/8/17), hvor Ekstra Bladets journalist i bedste detektivstil er taget til Brøndby Havn ud til Køge Bugt for at søge svar på krimigåden. Dykkere leder på det tidspunkt efter Kim Walls lig i bugten. Her interviewer journalisten to mænd, selvom "ingen af de to var ude at sejle, mens ubådsdramaet foregik", som journalisten skriver. Hermed mister de troværdighed, da de ikke er førstehåndsvidner. Tværtimod virker interviewet som en kaffebordssnak, hvor mændene for eksempel siger, at "(...) det ikke giver spor mening at lede efter et lig, som ifølge de to vil være stort set umuligt at finde, hvis det er på havets bund". Samtidig fremgår det, at de (mine kursiveringer) "desuden føler sig overbeviste om, at politiet måske har kunnet skaffe oplysninger om mobiltelefoner om bord på ubåden og master på land, og at det kan vore med til at pege på, at båden kan have voeret $\mathrm{i}$ Køge Bugt”. Dermed optræder de som en form for efterforskningseksperter, der dog ikke ved noget, men i stedet føler det, selvom deres eneste kompetence er at befinde sig i en sejlbåd i havnen.

I forhold til vidnerne bevæger journalisterne sig her i en presseetisk gråzone i balancen mellem på den ene side spændende jagt-på-svar-reportager og på den anden side et krav om relevante historier baseret på korrekt information og troværdige kilder. De første vidneberetninger synes legitime, da der er tale om førstehåndsvidner, og det kan have almen interesse at kortlægge, hvad der er gået forud for det mulige drab. Pseudovidnerne synes imidlertid at være et udtryk for en ekstrem efterspørgsmål på vinkler i sagen, og dermed ender journalisten med at gå på kompromis med almindelige principper for kildekritik og publicere en reportage, der bygger på researchkilder uden reel viden. Historien kan imidlertid skabe identifikation og har formentlig læserappel, fordi mange på det tidspunkt har diskuteret, hvor Wall kan være, og at dykkerne er på en umulig opgave, hvorfor man kan spejle sig i den samtale, mændene har med hinanden og journalistdetektiven, selvom ingen af dem har set noget. 


\section{Når den sigtede er kendt - særlig risiko for forhåndsdom?}

I (kriminal)journalistikken skelner man - ligesom man gør inden for for eksempel jura og andre fagfelter - mellem offentlige og ikke-offentlige personer, og det skal have almen interesse, hvis den sigtedes eller dømtes navn nævnes (Røssland 2003:132). I ubådssagen besidder den hovedmistænkte imidlertid ikke et væsentligt offentligt embede, men er derimod "bare" en kendis (Meyers 1993:140), som Ekstra Bladets læsere er interesseret i at høre om, eftersom den excentriske Raket-Madsen pludselig står midt i en potentiel mordgåde. Ubådssagen begyndte endvidere som en tragediefortælling, hvor Peter Madsen havde mistet sit kæreste eje, ubåden, og dermed var historiens offer, hvorfor journalisterne helt fra start identificerede ham i spalterne. Men han bliver hurtigt drabssigtet, og i de løbende beskrivelser af ham minder journalisternes tilgang om politiefterforskernes, da disse arbejder med at kortlægge den sigtedes såkaldte moralske karriere. Det vil sige, at de søger efter særlige personlighedstræk eller hændelser fra fortiden, der kan have formet ham som potentiel drabsmand (Innes 2003:170ff). Politiet konstruerer en form for afvigerportræt af den mistænkte "(...) in an attempt to produce an image of the 'pathological' individual who commits murder (ibid:172). På samme måde researcher journalisterne på Madsens fortid, men igen er forskellen, at kun journalisterne og ikke politiet er underlagt et publiceringskrav, der både handler om korrekte informationer og appellerer til følelserne.

I forhold til den konkrete efterforskningsproces ved man allerede i slutningen af august 2017, at det er Kim Walls torso, der blev fundet i vandkanten på Vestamager, men at Madsen nægter at have parteret hende. Den blodige og mystiske kontekst har læserne naturligvis med sig, når de læser Ekstra Bladets artikler i månederne efter, fordi man søger svar på, hvorvidt han virkelig har skåret hoved, arme og ben af hende. Flere af Ekstra Bladets artikler har tydeligt karakter af det, man kan kalde patologiske portrætter. I artiklen Manden med de to ansigter (EB, 24/9), der også er titlen på en kriminalroman af Gunnar Staalesen fra 1985, præsenteres læseren for en Dr. Jekyll-Mr. Hyde-karakter, hvormed journalisten trækker på en velkendt fiktionsfigur. I under- 
overskriften står der: "Manisk, empatisk og kolerisk: Den drabssigtede Peter Madsen beskrives som en modscetningsfuld person, der har to sider." Hermed beskrives han som en, der (måske) har potentiale som monster, der både kan partere lig og myrde. Det samme sker i artiklen Sådan blev han Raket-Madsen (EB, 16/10), hvor journalister søger svar i barndommen til at forklare hans mulige udvikling til drabsmand. På dette tidspunkt har obduktionsrapporten afWalls torso vist en række stik i underlivet. Dertil opremses såkaldte risikofaktorer - omsorgssvigt, manglende forældreopsyn, konflikter i hjemmet - som ifølge kriminologien viser en sammenhæng mellem opvækst og senere kriminalitet (Mannov 2013:150). Journalisterne skriver: "En ustabil barndom med svigt, en gammel kantet far, en fravorende mor, utallige flytninger og eksklusion har formet Peter Madsen, før han blev hyldet som raket-geni og nu er sigtet for drab". For at kvalificere dette drabsmandspotentiale anvender Ekstra Bladet også en ekspertkilde, nemlig psykiater Henrik Day Poulsen, der i artiklen Psykiater: Barndommen er afgørende (EB, 16/10) ved siden af portrættet forklarer, at manglen på "følelsesmcessigt modspil fra forceldrenes side gør også, at man selv kan blive følelsesmaessigt forvirret og nogle gange også følelsesmoessigt afstumpet, hvis man ikke loerer, hvad empati er”. Han sandsynliggør altså, at Madsens dårlige barndom kan have gjort ham afstumpet. Journalisten kan ikke dokumentere dette, hvorfor det også fremgår af artiklen, at psykiateren ikke kender "noermere til Peter Madsen, men udtaler sig generelt".

Journalisten skriver aldrig eksplicit, at Madsens splittede personlighed eller dårlige barndom gør ham til en kvindemishandler og drabsmand. Men ved at trække på overordnede fiktionsfortællinger og bringe detaljerede beskrivelser af omsorgssvigt i et koldt hjem, sammenstillet med en eksperts generelle udtalelser, så tegnes der alligevel samlet et billede af en mand, der "har det i sig". Det presseetiske dilemma handler her om risikoen for forhåndsdom versus en fascinerende og detaljeret fortælling om en berømt mand, vi troede, vi kendte. Ved hjælp af overordnede kendte fortællinger fra fiktionens verden fortæller journalisten kun indirekte læseren, at Peter Madsen måske har et monster gemt i sig - og påstår det altså ikke direkte. Dertil anvendes en 
ekspertkilde - psykiateren - til at koble den konkrete viden om Madsens barndom til noget generelt om, hvad der kan være med til at forme en afstumpet morder, hvormed man undgår at fastslå, at det faktisk er sådan. Udfordringen er imidlertid, at ekspertens generelle udtalelser kan opfattes meget konkrete, når de sammenstilles med Peter Madsen-beskrivelserne, og dermed er der en risiko for, at han i offentligheden er dømt på forhånd.

I slutningen af oktober 2017 erkender Peter Madsen at have parteret Kim Walls lig, og han sigtes nu også for "anden kønslig omgang end samleje under særlig skærpende omstændigheder" på grund af stik i underlivet, hvilket han nægter sig skyldig i. Journalisterne forsøger at hjælpe læseren til at forstå det uforståelige, nemlig hvordan han kunne partere - og måske sexmishandle og dræbe - Kim Wall. Madsens egen forklaring om, at han gjorde det for at få Wall ud af ubåden, synes ikke fyldestgørende for journalisterne (og læserne). Derfor søges der en forklaring i hans personlighed, hvilket helt klart også har mere følelsesappel end den "lavpraktiske" forklaring. Flere steder beskrives et uhyggeligt mørke, hvilket dramaturgisk trækker på nogle grundlæggende myter (Lule 2001), hvor det onde for eksempel personificeres af en djævlefigur. Det sker i flere artikler, for eksempel i Mørket om Peter Madsen (EB, 27/12/17), hvor forfatteren Djursing reflekterer over, hvorvidt Madsen har fyldt ham med løgn. I en senere artikel fortæller en tidligere laboratoriekollega på samme vis, at Madsen "må have skjult en mørk side for os alle sammen" (EB, 7/3/18). Disse "alle sammen" imødekommer de læsere, som også føler sig narret til at have troet, at Peter Madsen blot var en charmerende ubådsbygger. Samtidig får man via mørkefortællingerne tegnet et klart billede af en manipulerende psykopat, der har levet et hemmeligt dobbeltliv. Det presseetiske dilemma handler her om balancen mellem på den ene side læsernes krav om forklaring og spændende fortællinger, der trækker på fiktionen, og på den anden side kravet om korrekte meddelelser og hensynet til Peter Madsen. Her kan diskuteres, om han i denne sammenhæng reduceres til en uhyggelig fiktionskarakter, hvormed der er en risiko for, at læserne glemmer, at der er tale om et menneske, der endnu ikke er dømt for en forbrydelse. 


\section{Konklusion}

Studiet af ubådssagen diskuterer presseetiske dilemmaer, der kan opstå, når Ekstra Bladets journalister i fiktionsdetektivstil efterligner politiets efterforskningsproces. Studiet dokumenterer en række praksisser, hvor kriminalreporterne på den ene side forsøger at levere fascinerende fortællinger med følelsesappel, der kan hjælpe læseren til delvist at forstå det uforståelige, selvom både journalister og offentlighed udfordres af manglen på faktuel information. Og på den anden side er journalisterne underlagt kravet om god presseskik, hvorfor de opfordres til at bringe korrekte informationer, ikke må dømme på forhånd og skal tage hensyn til individet. Gennem en tekstnær analyse diskuteres de presseetiske gråzoner, der forekommer, når journalistdetektiverne i jagten på nye vinkler 1) skriver om mulige motiver, 2) inddrager vidner, 3) leverer detaljerede personbeskrivelser og sandsynliggør Peter Madsen som monster ved at koble sig på velkendte fiktionsfortællinger/karakterer samt 4) lader især ekspertkilder udtale sig generelt og med mange forbehold.

Med afsæt i ovenstående er det oplagt, at fremtidige forskningsprojekter sætter yderligere fokus på dilemmaerne, der opstår i kriminaldækning. Det vil forhåbentlig kunne skabe et endnu mere konkret begrebsapparat til meningsfulde analyser og diskussioner af det presseetiske grænseland, journalister og medier arbejder i, når kriminalsager dækkes.

\section{NOTER}

1 Dette studie undersøger ikke hele dækningen af ubådssagen. Men for at få en fornemmelse af omfanget kan det noteres, at Infomedia registrerede over 12.000 artikler og indslag i danske medier i perioden 11. august 2017 - 25. marts 2018. I de første 18 dage blev der ifølge mediet bias.dk skrevet omkring 30.000 artikler verden over (Meidell 2017).

\section{REFERENCER}

Agger, Gunhild (2013). Mord til tiden. Aalborg: Aalborg Universitetsforlag.

Allern, Sigurd (2013). "Kriminaliteten og medierne”. Nordisk Tidsskrift for Kriminalvidenskab, 100. årgang, nr. 3, pp. 313-323. 
Andersen, Michael Bruun (2006). "Fra presseetik til markedsmoral". Journalistica, 1. årgang, nr. 1, pp. 25-41.

Anonym (2016). Ord på gullvekt - et empirisk blikk på forhåndsdømming i norsk kriminaljournalistik og i Sigrid-saken. BA-opgave, Oslo: Høgskolen i Oslo og Ankershus.

Bjerg, Lars (2009). Den gode journalist. Aarhus: Ajour.

Blach-Ørsten, Mark og Burkal, Rasmus (2014). "Credibility and the media as a political institution”. Nordicom Review, 35. årgang, særudgave, pp. 67-79.

Blach-Ørsten, Mark, Møller, Jannie Hartley, Flensburg, Sofie \& Olsen, Maria Bendix (2015). Medieetik - mediernes udvikling i Danmark 2015. Specialrapport, København: Kulturstyrelsen.

Blach-Ørsten, Mark, Lund, Anker Brink \& Burkal, Rasmus (2015). "Institutionel troværdighed - en analyse af nyhedsmediernes troværdighed som samfundsinstitution", pp. 10-34 i Mark Blach-Ørsten \& Anker Brink Lund (red.), Trovardig journalistik. København: Samfundslitteratur.

Bondebjerg, Ib (2002). “Med politiet i 'virkeligheden': Reality-tv og kriminalitet”. MedieKultur, 18. årgang, nr. 34, pp. 62-77.

Borberg, Vibeke (2012). Princippet om offentlighed i retsplejen. København: Jurist- og Økonomforbundet.

Brurås, Svein (2000). Etikk for Journalister. Bergen: Fagboklaget.

Brurås, Svein (2009). Kriminaljournalistikkens etikk - PFU-udttalelser belyst fra tre moralfilosofiske posisjoner. Ph.d.-afhandling. Bergen: Universitetet i Bergen.

Brurås, Svein og Røssland, Lars Arve (2005). Full skjæering - drabssaken, nyhetsjakten og menneskene bak nyheterne. Bergen: Universitetet $\mathrm{i}$ Bergen.

Buch, Roger (2006). "Journalisters syn på journalistisk etik”. Journalistica, 1. årgang, nr. 1, pp. 81-99.

Chibnall, Steve (1981). "Chronicles of the gallows: The social history of crime reporting”. The Sociological Review, 29. årgang, nr. 1, pp. 179217.

Chibnall, Steve (1975). “The crime reporter: A study in the production of commercial knowledge”. Sociology, 9. årgang, nr. 1, pp. 49-66.

Danielson, Magnus (2016). Den granskande makten. Ph.d.-afhandling. Stockholm: Stockholms Universitet.

Danske Dagblades Fællesrepræsentation (1960). God presseskik ved omtale af straffesager. Bilag i Straffelovrådets betcenkning om privat- 
livets fred. 1971, nr. 601, pp. 77-81, København: Schultz Bogtrykkeri.

Delbro, Danielle og Juliusson, Hanna (2017). Som Bron, fast på riktigt. Specialeafhandling. Göteborg: Göteborgs Universitet.

Dobovšek, Bojan og Mastnak, Matikja (2012). "Police detectives and investigative reporters working hand in hand against organized crime”, pp. 289-301 i Max Edelbacher, Peter C. Kratcoski \& Michael Theil (red.) Financial crimes: A threat to global security. New York: CRC Press.

Ekstrabladet.dk (2018). https://ekstrabladet.dk/Om_ekstra_bladet/ Journalistik/5812358 (besøgt den 10. november 2018).

Fengler, Susanne, Eberwein, Tobias, Mazzoleni, Gianpietro, Porlezza, Colin \& Russ-Mohl, Stephan (red.) (2014). Journalists and media accountability: An international study of news people in the digital age. New York: Peter Lang Publishing.

Flyvbjerg, Bent (2006). "Five misunderstandings about case-study research". Qualitative Inquiry, 12. årgang, nr. 2, pp. 219-245.

Frenningsmoen, Linn Elise (2006). Skyldig inntil det motsatte er bevist? - et søkelys på pressens rolle i to justismordsaker. Specialeafhandling. Oslo: Universitet i Oslo.

Grabe, Maria Elizabeth (2000). "Narratives of guilt: Television news magazine coverage of the O.J. Simpson criminal trial”. Howard Journal of Communications, 11. årgang, nr. 1, pp. 35-48.

Greer, Chris (2007). “News media, victims and crime”, pp. 21-49 i Pamela Davies, Peter Francis \& Chris Greer (red.) Victims, crime and society. London: Sage.

Innes, Martin (1999). “The media as an investigative resource”. British Journal of Criminology, 39. årgang, nr. 2, pp. 269-86.

Innes, Martin (2003). Investigating murder: Detective work and the police response to criminal homicide. Oxford: Oxford University Press.

Jensen, Leif Becker (1997). Indføring i tekstanalyse. Roskilde: Roskilde Universitetsforlag.

Katz, Jack (1987). “What makes crime 'news'?”. Media, Culture and Society, 9. årgang, nr. 1, pp. 47-75.

Keeble, Richard (2001). Ethics for journalists. London: Routledge. Kruuse, Helle Nissen (1991). Etik i journalistik. Aarhus: Ajour.

Kvam, Bjarne (2002). Krimjournalisten. Kristiansand: IJ-forlaget.

Larsen, Mia Than. (2010). Ekstra Bladet: Folkedommer eller formidler? En undersøgelse af god presseskik på Ekstra Bladet med Maria-mordet som case. Specialeafhandling. Roskilde: Roskilde Universitet. 
Lehrmann, Ulrik. 2011. "Tabloid crime journalism: Writing on the edge of existence”. Northern Lights, 9. årgang, pp. 179-192.

Lehrmann, Ulrik. 2016. Den daglige mordforsyning. Aalborg: Aalborg Universitetsforlag.

Lule, Jack (2001). "Seven master myths in the news", pp. 11-26 i Daily news, eternal stories - the mythological role of journalism. New York: The Guilford Press.

Lund, Anker Brink (2003). "Kriminalitet i danske massemedier”. Nordisk Tidsskrift for Kriminalvidenskab, årgang. 90, nr. 3, pp. 160-177.

Lund, Anker Brink \& Jensen, Henrik (2011). "Continuity and change in mass-mediated crime coverage: Content analyses of newspapers, television and web media”. Northern Lights, 9. årgang, pp. 159-177.

Mannov, Jonas (2013). "Psykologiske og biologiske teorier om kriminalitet”, pp. 149-166 i Michael Hviid Jacobsen \& Anne-Stina Sørensen (red.), Kriminologi - en introduktion. København: Hans Reitzels Forlag.

Mawby, Rob C. (2010). "Police corporate communications, crime reporting and the shaping of policing news". Policing and Society, 20. årgang. nr 1, pp. 124-139.

McBride, Kelly \& Rosenstiel, Tom (red.) (2014). The new ethics of journalism: Principles for the 21st century. Los Angeles: Sage.

Meidell, Rune Eklund (2017). http://www.bias.nu/ubaadssag-vaekkeropsigt-jorden-rundt/ (besøgt den 10. november 2018).

Meyers, Christopher (1993). "Justifying journalistic harms: Right to know vs. interest in knowing”. Journal of Mass Media Ethics, 8. årgang, nr. 3, pp. 133-146.

Orre, Inger (2001). Reporterskap: berättelser, irrbloss, dygder. Ph.d.afhandling. Stockholm: Tekniska högskolan.

Patton, Michael Quinn (2002). Qualitative Research and Evaluation Methods. London: Sage.

Pollack, Ester (2001). En studie $i$ medier och brott. Ph.d.-afhandling. Stockholm: Stockholms Universitet.

Pressenævnet (2013). Vejledende regler for god presseskik, http://www. pressenaevnet.dk/god-presseskik/ (besøgt den 11. november 2018).

Røssland, Lars Arve (2003). Kriminelt: Kriminaljournalistikk i norske popularmedium. Oslo: Universitetsforlaget.

Røssland, Lars Arve, Brurås Svein \& Østbye, Helge (2006). Morderjakt og mediemakt. Oslo: Cappelen Akademisk Forlag.

Shpayer-Makov, Haia (2009). "Journalists and police detectives in Vic- 
torian and Edwardian England: An uneasy reciprocal relationship". Journal of Social History, 42. årgang, nr. 4, pp. 963-986.

Skovbjerg, Annegrete \& Jørgensen, Oluf (2006). "Presseetisk Kontrol”. Journalistica, 1. årgang, nr. 1, pp. 43-60.

Sparre, Kirsten (2002). Politiet som kilde. Rapport, Aarhus: CFJE.

Wardle, Claire (2006). “'It could happen to you': The move towards 'personal' and 'societal' narratives in newspaper coverage of child murder, 1930-2000”. Journalism Studies, 7. årgang, nr. 4, pp. 515-533.

Wright, Michelle (2013). "Homicide detectives' intuition”. Journal of Investigative Psychology and Offender Profiling 10(2):182-199.

\section{FORFATTER}

Maria Bendix Wittchen

Studielektor, Roskilde Universitet

mbendixw@ruc.dk 